\title{
Individual and population level effects of ocean acidification on a predator-prey system with inducible defenses: bryozoan-nudibranch interactions in the Salish Sea
}

\author{
Sasha K. Seroy ${ }^{1,2, *}$, Daniel Grünbaum ${ }^{1,2}$ \\ ${ }^{1}$ School of Oceanography, University of Washington, Seattle, Washington 98105, USA \\ ${ }^{2}$ Friday Harbor Laboratories, University of Washington, Friday Harbor, Washington 98250, USA
}

\begin{abstract}
Ocean acidification (OA) from increased oceanic $\mathrm{CO}_{2}$ concentrations imposes significant physiological stresses on many calcifying organisms. OA effects on individual organisms may be synergistically amplified or reduced by inter- and intraspecies interactions as they propagate up to population and community levels, altering predictions by studies of calcifier responses in isolation. The calcifying colonial bryozoan Membranipora membranacea and the predatory nudibranch Corambe steinbergae comprise a trophic system strongly regulated by predatorinduced defensive responses and space limitation, presenting a unique system to investigate OA effects on these regulatory mechanisms at individual and population levels. We experimentally quantified OA effects across a range of $\mathrm{pH}$ from 7.0 to 7.9 on growth, calcification, senescence and predator-induced spine formation in Membranipora, with or without waterborne predator cue, and on zooid consumption rates in Corambe at Friday Harbor Laboratories, San Juan Island, WA. Membranipora exhibited maximum growth and calcification at moderately low $\mathrm{pH}$ (7.6), and continued spine formation in all $\mathrm{pH}$ treatments. Spines reduced Corambe zooid consumption rates, with lower $\mathrm{pH}$ weakening this effect. Using a spatially explicit model of colony growth, where colony area serves as a proxy for colony fitness, we assessed the population-level impacts of these experimentally determined individual-level effects in the context of space limitation. The area-based fitness costs associated with defense measured at the individual level led to amplified effects predicted for the population level
\end{abstract}

*Corresponding author: sseroy@uw.edu

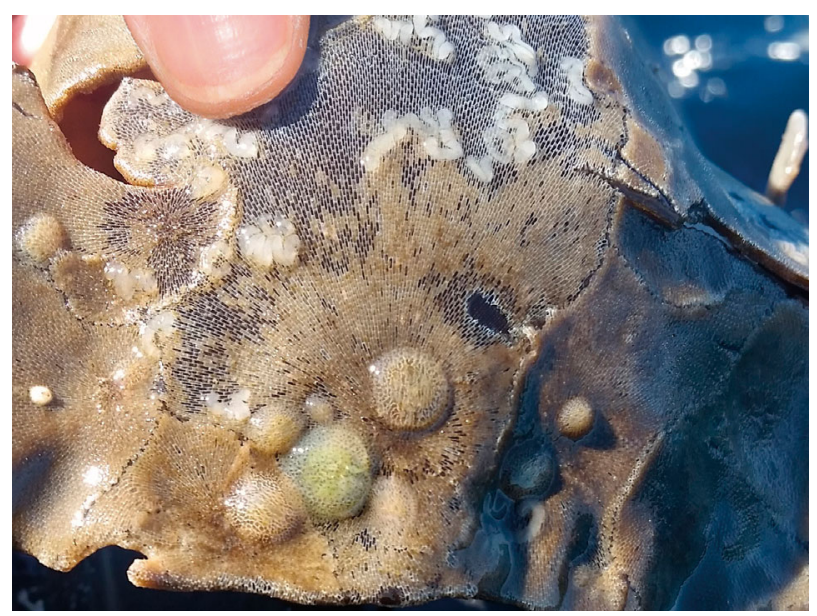

Predatory nudibranchs Corambe steinbergae (gelatinous, at the bottom) preying on zooids of the colonial bryozoan Membranipora membranacea. Zooids emptied by C. steinbergae, and $C$. steinbergae egg clutches, are visible in the upper part of the photo.

Photo: Sasha K. Seroy

due to competition. Our coupled experimental and modeling results demonstrate the need to consider population-level processes when assessing ecological responses to stresses from changing environments.

KEY WORDS: Predator-prey interactions - Ocean acidification · Inducible defenses $\cdot$ Space competition · Modeling $\cdot$ Membranipora membranacea $\cdot$ Corambe steinbergae

() The authors 2018. Open Access under Creative Commons by Attribution Licence. Use, distribution and reproduction are unrestricted. Authors and original publication must be credited. 


\section{INTRODUCTION}

Ocean acidification (OA) resulting from increased oceanic uptake of atmospheric carbon dioxide presents a variety of environmental stresses to marine organisms and ecosystems (Hofmann et al. 2010, Kroeker et al. 2013). OA causes a decrease in both pH and carbonate ion availability (Feely et al. 2009), often with negative physiological implications for many organisms (Kroeker et al. 2013). Global pH levels have been declining, with continued projections of 0.3-0.4 units within the next century (Feely et al. 2004, 2009). Coastal areas, however, often experience natural $\mathrm{pH}$ fluctuations that currently exceed these predicted changes (Doney 2010, Hofmann et al. 2010). In the Salish Sea and San Juan Archipelago, WA, USA, naturally low seawater pH levels result from regular upwelling and river input (Murray et al. 2015). While open ocean $\mathrm{pH}$ averages well above 8.0 (Doney 2010), the San Juan Archipelago experiences $\mathrm{pH}$ around 7.8 and can reach as low as 7.67 in San Juan Channel during seasonal upwelling (Sullivan 2012, Murray et al. 2015). Consequently, the Salish Sea is a natural laboratory to investigate OA effects where organisms already experience $\mathrm{pH}$ values that open ocean organisms will likely not experience until the end of the century.

Organisms that make shells or skeletons from $\mathrm{CaCO}_{3}$ are common in the Salish Sea, with a third of Puget Sound species identified as calcifiers (Busch \& McElhany 2017). Calcifying organisms have been demonstrated to be generally vulnerable to acidification (Kroeker et al. 2013). Decreasing availability of $\mathrm{CO}_{3}{ }^{2-}$ can impede calcification (Feely et al. 2009). In conjunction, the dissolution of calcified structures is favored by the low-saturation states of $\mathrm{CaCO}_{3}$ polymorphs, calcite and aragonite, that often accompany OA (Orr et al. 2005). Calcifier responses to OA have been generally negative, with many organisms exhibiting decreased growth, survival and calcification rates (Kroeker et al. 2013). Some taxa, however, have displayed no effect or even positive effects, demonstrating the importance of quantifying speciesspecific responses in diverse taxa (Ries et al. 2009). Variable OA responses have been attributed to a number of potential causes, including diversity of calcification mechanisms, presence and thickness of protective organic membranes and solubility of different $\mathrm{CaCO}_{3}$ polymorphs in addition to differences in capacity for plasticity and prior exposure to low $\mathrm{pH}$ (Ries et al. 2009).

While most studies document OA effects on calcifiers in isolation, the true ecological consequences of these stresses occur within interconnected species networks that ultimately structure populations and communities. Skeletal mineralogy alone is an incomplete predictor of OA sensitivity, especially in the context of trophic interactions where direct and indirect effects associated with species interactions may be significant (Busch \& McElhany 2017). Physiological and behavioral processes in both predators and prey may be impacted differently by OA. These alterations potentially amplify or reduce organism-level effects of OA on population and community levels, highlighting the importance of considering predator-prey interactions when conducting OA studies (Kroeker et al. 2014). For example, OA may impair predator detection mechanisms, resulting in reduced predator avoidance behavior in fish (Dixson et al. 2010) and marine snails (Manríquez et al. 2013), but can reduce predation by crabs on oysters (Dodd et al. 2015). In these examples, the differential effects of OA on distinct trophic levels indicate a potential for environmental stress to impact populations and communities to different extents and in different directions than suggested by studies of species in isolation. The potential of OA to alter predator-prey interactions, and how these effects may propagate to populations and communities, however, remains poorly understood.

Inducible defenses are an important subset of predator-prey interactions that confer protection to organisms upon the detection of environmental cues of impending predation (Harvell 1990). When defenses incur significant costs, inducibility allows organisms to maximize the benefit of being defended when under attack while avoiding the cost of defense when predation risks are low (Tollrian \& Harvell 1999, Ferrari et al. 2010). Predator-induced defenses are common in marine calcifiers, e.g. shell thickening in oysters (Lord \& Whitlatch 2012, Scherer et al. 2018), snails (Trussell \& Nicklin 2002, Bourdeau 2010), and mussels (Leonard et al. 1999). OA has been found to affect inducible defenses in some species. Both induced shell thickening in the snail Littorina obtusata (Bibby et al. 2007) and predatorinduced neck teeth in freshwater Daphnia spp. were reduced by high partial pressure of carbon dioxide $\left(\mathrm{pCO}_{2}\right)$ (Weiss et al. 2018). While these studies have investigated the effects of acidification on inducible defenses, few have done so in the context of multiple levels of biological organization.

Inducible defenses can have effects beyond the organism level, with potential propagating effects through food webs and population dynamics of both predators and prey (Miner et al. 2005), which suggests that OA effects on these interactions must 
then be assessed at population and community levels. Scaling organism-level interactions to estimate population-level responses can provide quantitative assessments of propagating effects of OA. In this study, we used a well-known inducible defense system to develop a strategy for assessing OA effects in which we empirically measured individual-level responses and used a numerical model to infer population-level effects.

The encrusting bryozoan Membranipora membranacea (hereafter Membranipora) is an abundant colonial epibiont on kelp in the Salish Sea and San Juan archipelago (Fig. 1). Larval recruitment occurs in late spring, with populations colonizing kelp blades as they grow throughout the summer (Seed 1976). Colonies do not typically overgrow each other, and instead divert energy to reproduction when occluded (Harvell \& Padilla 1990). Membranipora are ecologically significant invasive biofouling organisms along the east coast of North America, where overgrowth on kelp can cause kelp deforestation (Scheibling \& Gagnon 2009, Saunders et al. 2010), especially where specialist nudibranch predators are not prevalent (Lambert et al. 1992) and other predators prefer different bryozoans (Pratt \& Grason 2007). Membranipora colonies consist of multiple, genetically identical zooids (Harvell 1984) partially encased in a calcium carbonate skeleton (Smith et al. 2006, Taylor et al. 2015). Larger colonies consist of more zooids, leading to higher reproductive output than colonies with fewer zooids, making space an important limiting resource for Membranipora (Yoshioka 1982a). The cryptic nudibranch Corambe steinbergae (hereafter Corambe) exerts strong episodic predation pressure on Membranipora, feeding by sucking individuals out of zooids, leaving them empty (Yoshioka 1982b). In response, Membranipora exhibits an inducible defense by forming protective chitinous spines upon de- tecting waterborne chemical cues from Corambe. Spines are produced only on newly formed zooids at the growing margin of the colony, requiring the formation of new calcified zooids (Harvell 1984). Spination begins with formation of corner spines on zooid vertices, followed by additional spines along the walls of the zooids (Harvell 1984). Spines have been demonstrated to be effective in reducing predation (Harvell 1986). However, spines also have associated costs, including reduced colony growth as resources are allocated for defense (Harvell 1986, 1992) and disruption of feeding currents (Grünbaum 1997).

The Membranipora-Corambe system presents a uniquely informative opportunity to understand the consequences of OA effects and predator-prey interactions across multiple scales of biological organization. Membranipora colonies are primarily mineralogically composed of aragonite and low-Mg calcite (Smith et al. 2006), which may affect their ability to grow and calcify in OA conditions. Aragonite is a highly soluble polymorph of $\mathrm{CaCO}_{3}$, and some heavily calcified bryozoans have been identified as potential bioindicators of OA given their vulnerability (Smith 2009, Fortunato 2015, Taylor et al. 2015). Membranipora is a tractable experimental system, as its modular architecture allows for a single genotype to be divided into multiple experimental treatments. This effective control for genetic variation facilitates quantifying the plastic capabilities of specific genotypes (Harvell 1990). Both the deployment of defense (inducible spine formation) and the degree of predation (consumed zooids) are easily and non-destructively quantifiable. Finally, organizational levels of this system, from zooid to population, are inherently linked by zooid-level processes such as spine formation, which alter colony growth dynamics and ultimately influence space competition and, consequently, fitness.

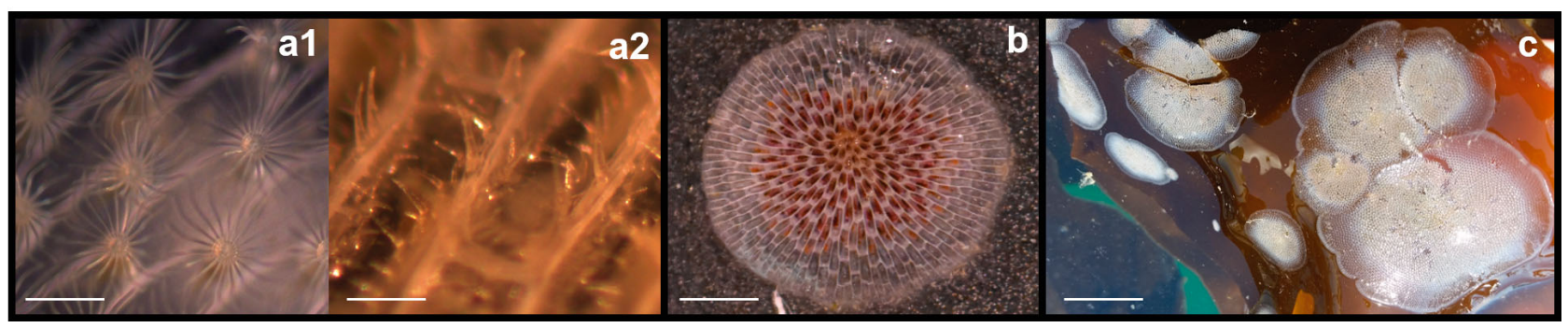

Fig. 1. Tightly linked multiple levels of biological organization in the bryozoan Membranipora membranacea make it a uniquely informative organismal system in which to investigate OA effects at multiple levels. Individual zooids within a colony: (a1) feeding, undefended zooids (with no spines), and (a2) spines formed along zooid walls of defended zooids. (b) One Membranipora colony comprising many genetically identical zooids with older, developed zooids at the center and younger developing zooids along the perimeter. (c) Multiple colonies competing for space on a kelp blade, with larger colonies occluding smaller colonies. From left to right scale bars are $300 \mu \mathrm{m}, 250 \mu \mathrm{m}, 3 \mathrm{~mm}$ and $5 \mathrm{~cm}$ 
Membranipora presents a good system for constructing population dynamics models because space competition and reproductive potential, mediated by variations in predation and colony growth rates, can be represented as a spatially explicit process analogous to observable distributions in the field. Using this system to explore connections between individuals and populations, modeled growth patterns which scale up individual responses can provide some insight on OA impacts on predicted area-based fitness and costs of defense under space limitation. Therefore, Membranipora presents an exceptional opportunity to understand population-level implications of an organism-level anti-predator mechanism under OA stress.

The goals of this study were to (1) experimentally quantify the colony-level effects of OA on Membranipora growth, $\mathrm{CaCO}_{3}$ production and formation of defensive spines, along with rate of predation by Corambe, and (2) use modeling approaches to infer the consequences of observed colony-level impacts at the population level. We addressed the following questions: (1) How does a range of $\mathrm{pH}$ reflecting mild to severe OA affect Membranipora colony growth, $\mathrm{CaCO}_{3}$ production and inducible spine formation and Corambe predation rates on Membranipora? (2) How are predicted organism-level effects of OA and predator cues altered by the inclusion of populationlevel processes (e.g. space competition among Membranipora colonies)?

We hypothesized that, at the colony level, growth and $\mathrm{CaCO}_{3}$ production would be reduced by OA in the absence of predator cues, and that reductions in growth would be compounded in the presence of predator cue due to the cost of defense. On the population level, we predicted the associated costs of these growth rate reductions would be further amplified by space competition. We also hypothesized that inducible spines, although chitinous, would be reduced by OA since they form on areas of new growth which require the formation of new calcified skeleton, and that predation rates would be reduced due to direct effects of OA stress on organisms.

\section{MATERIALS AND METHODS}

\section{Bryozoan collection and preparation}

Membranipora colonies were collected off the floating dock at Friday Harbor Laboratories (FHL) $\left(48.546^{\circ} \mathrm{N}, 123.013^{\circ} \mathrm{W}\right)$ in Spring 2017 . Racks of several plastic plates, each $\sim 20 \mathrm{~cm} \times 40 \mathrm{~cm} \times 1.5 \mathrm{~mm}\left(8^{\prime \prime} \times\right.$ $\left.16^{\prime \prime} \times 1 / 16^{\prime \prime}\right)$, were deployed for 1 mo beginning in late April to collect settling larvae. Plates were recovered in late May and transferred to laboratory sea tables reflecting collection site conditions. Colonies with at least a $5 \mathrm{~cm}$ radius of free space were selected as target colonies and cut from the plastic plate using a bandsaw, to produce $10 \times 10 \mathrm{~cm}$ plates with 1 colony at the center. To minimize shock, colonies were returned to sea tables for $3 \mathrm{~d}$. Other colonies surrounding the target colony were cleared from the plastic plate to prevent interference. This allowed sufficient area for new growth throughout the duration of the experiment, such that in no colony was space limited. Target colonies were dyed with a $200 \mathrm{mg} \mathrm{l}^{-1}$ solution of Alizarin Red S (Sigma Aldrich) in filtered seawater for $18 \mathrm{~h}$ and flushed for $6 \mathrm{~h}$, to mark the initial colony area (Saunders \& Metaxas 2009). $10 \times 10 \mathrm{~cm}$ plastic plates with target colonies were scored with a razor blade, broken into separate quarters and returned to sea tables for $24 \mathrm{~h}$ prior to the experiment. A total of 24 colonies (distinct genotypes) were included in the experiment. Twelve colonies were exposed to waterborne predator cue of Corambe, and 12 received no predator cue, with each colony genotype fully replicated (roughly equal colony sections) across 4 nominal $\mathrm{pH}$ treatments: 7.0, 7.3, 7.6 and 7.9 (Fig. S1 in Supplement 1 at www.int-res.com/articles/suppl/ m607p001_supp/). We used regression-based approaches to establish Membranipora response curves, which could be easily integrated into a population dynamics model.

\section{Experimental setup}

In total, 4 tanks were used in the FHL Ocean Acidification Environmental Laboratory (OAEL) to establish each of these $\mathrm{pH}$ conditions by bubbling $\mathrm{CO}_{2}$ as described by O'Donnell et al. (2013). Temperature in tanks was maintained at $13^{\circ} \mathrm{C}$, reflecting typical ambient temperature at the collection site during the summer months (Murray et al. 2015). Weekly water samples were taken for carbonate chemistry measurements including spectrophotometric $\mathrm{pH}$ (total scale) and total alkalinity in accordance with best practices (Reibesell et al. 2010). $\mathrm{CO}_{2}$ Sys v.1.05 (Pierrot et al. 2006) was used to calculate additional carbonate system parameters from measured $\mathrm{pH}$, total alkalinity, salinity and temperature (Table 1). Temperature and $\mathrm{pH}$ were monitored continuously throughout the experiment using Durafet electrodes, which were calibrated weekly. Tanks included a total of 8 isolated chambers, 6 of which were used to contain 4 Mem- 
Table 1. Average $( \pm 1 \mathrm{SD})$ carbonate chemistry data for experimental seawater tank treatments at the Ocean Acidification Environmental Laboratory (OAEL). Total alkalinity (TA) and salinity were measured weekly and pH (total scale) in tank chambers was monitored daily throughout the study. Additional carbonate system parameters (dissolved inorganic carbon [DIC], partial pressure of carbon dioxide $\left[\mathrm{pCO}_{2}\right]$, aragonite saturation state $\left[\Omega_{\mathrm{Ar}}\right]$ ) were calculated using $\mathrm{CO}_{2}$ Sys (Pierrot et al. 2006)

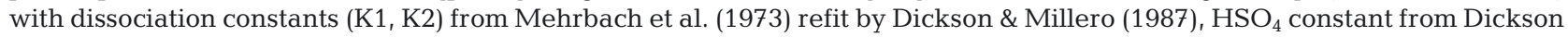
(1990) and Boron constant from Lee et al. (2010)

\begin{tabular}{|c|c|c|c|c|c|c|c|}
\hline $\begin{array}{l}\text { Target } \\
\mathrm{pH}\end{array}$ & $\begin{array}{l}\text { Temp } \\
\left({ }^{\circ} \mathrm{C}\right)\end{array}$ & $\begin{array}{l}\text { Salinity } \\
\text { (psu) }\end{array}$ & $\begin{array}{c}\mathrm{pH} \\
\text { (total scale) }\end{array}$ & $\begin{array}{c}\text { TA } \\
\left.(\mu \mathrm{mol} \mathrm{kg})^{-1}\right)\end{array}$ & $\begin{array}{c}\text { DIC } \\
\left.(\mu \mathrm{mol} \mathrm{kg})^{-1}\right)\end{array}$ & $\begin{array}{c}\mathrm{pCO}_{2} \\
\text { ( } \mu \text { atm) }\end{array}$ & $\Omega_{\mathrm{Ar}}$ \\
\hline 7.0 & $12.8 \pm 0.1$ & $28.6 \pm 0.1$ & $7.13 \pm 0.06$ & $2022 \pm 19$ & $2141 \pm 32$ & $3462 \pm 504$ & $0.23 \pm 0.03$ \\
\hline 7.3 & $13.3 \pm 0.3$ & $29.2 \pm 0.1$ & $7.38 \pm 0.02$ & $2024 \pm 25$ & $2060 \pm 27$ & $1937 \pm 94$ & $0.44 \pm 0.02$ \\
\hline 7.6 & $13.3 \pm 0.2$ & $28.9 \pm 0.1$ & $7.66 \pm 0.03$ & $2022 \pm 19$ & $1984 \pm 21$ & $986 \pm 74$ & $0.81 \pm 0.05$ \\
\hline 7.9 & $13.2 \pm 0.1$ & $29.0 \pm 0.3$ & $7.88 \pm 0.02$ & $2023 \pm 20$ & $1920 \pm 21$ & $589 \pm 28$ & $1.30 \pm 0.05$ \\
\hline
\end{tabular}

branipora colony sections each. Within each tank, 3 chambers received water pre-treated with predator cue from a separate chamber which housed Corambe, to induce defensive spines without actual predation. The predator chambers contained 12 nudibranchs for a final concentration of 4 nudibranchs $1^{-1}$, exceeding the threshold concentration required to induce a defensive response (Harvell 1986). Surface area of each nudibranch was measured prior to the experiment, and distributed such that each predator chamber had 12 similarly sized nudibranchs with a total surface area of approximately $130 \mathrm{~mm}^{2}$. Another 3 chambers served as controls, receiving water not treated with predator cue. All chambers received source water from the main tank with independent inflow and outflow lines such that chambers did not share water, which allowed us to restrict predator cue to only predator cue treatments. However, we potentially experienced minor contamination of predator cue in control treatments due to occasional overflows of predator cue chambers into the main water source, which may have created diffuse predator cue water for control treatments. Four colony sections were randomly assigned to each tank chamber, and rotated among chambers within a treatment every $2 \mathrm{~d}$ to control for chamber effects. One predator-exposed colony section was damaged during the experiment and all corresponding sections of that colony were removed. The flow-through system was plumbed with unfiltered seawater and each chamber was fed 50000 cells ml $^{-1}$ of Isochrysis galbana and 5000 cells ml-1 of Dunaliella sp. 3 times daily to encourage bryozoan growth.

\section{Part 1: Bryozoan growth, senescence and inducible defense formation}

A paddle system constructed from PVC pipe and a motor (Strathmann 2014) above each OAEL tank generated mixing in each chamber sufficient to keep algal cells suspended to ensure effective Membranipora feeding. Colony sections on plastic squares were attached to swinging paddles using rubber bands, and exposed to experimental treatments for $15 \mathrm{~d}$. Growth and zooid senescence were monitored for each colony section using photographs taken every 5 d with a Nikon D3400 camera with macro lens. Colony section surface area was measured in ImageJ. Colony section growth rates were calculated as the exponential rate of increase in surface area, because colony area increases roughly in proportion to the number of feeding zooids. Growth rates were calculated by solving for $r$ using the equation below, where $A_{t_{15}}$ is the colony surface area after $15 \mathrm{~d}, A_{t_{0}}$ is the initial colony surface area and $t$ is the duration of the experiment $(15 \mathrm{~d})$ :

$$
A_{t_{15}}=A_{t_{0}} \mathrm{e}^{r t}
$$

Zooids in photos were classified as feeding (fully developed), developing, or degenerated (brown body), and counted using the ImageJ cell counter plugin. Fully developed zooids had a full gut (see center zooids in Fig. 1b) while developing zooids could not yet feed and did not yet have a developed gut (see peripheral zooids in Fig. 1b). Degenerated zooids referred to senesced zooids, not those consumed via predation. To assess spine length and quantity, a Lumenera Infinity microscope camera mounted on a dissecting microscope was used to take photo transects for each colony section. Colonies were held at a $45^{\circ}$ angle for photographing using a $3 \mathrm{D}$ printed mount and a micromanipulator. For each colony section, 3 uniform transect lines, $1 \mathrm{~cm}$ apart, were photographed through the new growth area and stitched together. The length of the closest corner spine to each of 5 randomly selected locations along each transect line was measured and corrected for the photographing angle. 


\section{Part 2: Nudibranch feeding rates}

After colonies received a $15 \mathrm{~d}$ predator cue or control treatment and growth rates were measured in the absence of predation, 1 nudibranch was released on each colony section in each $\mathrm{pH}$ condition to determine feeding rates. Nudibranchs were starved and acclimated for $24 \mathrm{~h}$ in their respective feeding $\mathrm{pH}$ treatments before being placed on Membranipora colony sections. We measured nudibranch length (diameter in $\mathrm{mm}$ from photographs), sorted nudibranchs from shortest to longest and paired them with colony sections such that the longest nudibranch was placed with the colony section of the largest surface area. Nudibranch lengths ranged 2.52-8.73 $\mathrm{mm}$ with a mean length of $5.30 \mathrm{~mm}$. Initial photographs of colonies were taken to establish baseline conditions of zooids. All nudibranchs were initially placed on the center of the target colony's growing margin and confined by adding $300 \mu \mathrm{m}$ mesh cages with a 3D printed frame cable-tied to the swinging plastic paddles above each colony to prevent predation on colonies other than the target colony. Nudibranchs were allowed to consume zooids for a $24 \mathrm{~h}$ period, after which final photographs were taken and the number of empty zooids, from predation, were quantified.

\section{Part 3: Quantification of bulk calcium content in bryozoan skeletons using mass spectrometry}

One skeleton sample was taken from the new area grown during the experiment from each colony section. Skeleton samples were roughly $100 \mathrm{~mm}^{2}$ but were variable depending on available area of new growth in each colony section. Samples were transferred to a $35 \mathrm{~mm}$ Petri dish, and sequentially rinsed with milliQ water, a $10 \%$ bleach solution, a final milliQ rinse and $95 \%$ ethanol to dry out the sample. Areas of skeleton samples were measured in ImageJ. Each rinsed and dried skeleton sample was prepared in 2 parts ( $A$ and $B$ ) for elemental analysis to quantify Ca content as a proxy for bulk skeletal $\mathrm{CaCO}_{3}$ (similar to methods in Wood et al. (2008) and Findlay et al. (2011) that quantified total Ca). For Part A, skeletal samples were removed from their respective Petri dishes, weighed on a microbalance, dissolved in $2.5 \mathrm{ml}$ of $5 \% \mathrm{HNO}_{3}$ and diluted to a final $5 \mathrm{ml}$ with milliQ water in a $15 \mathrm{ml}$ falcon tube. For Part B, residual skeletal material was rinsed into a $2.5 \mathrm{ml} 5 \%$ $\mathrm{HNO}_{3}$ solution and diluted to a final $5 \mathrm{ml}$ solution with milliQ water. A $10 \mathrm{ml}$ solution composed of $1 \mathrm{ml}$
Part A or B, $100 \mu \mathrm{l}$ of $100 \mathrm{ppb} \mathrm{Sc}_{\text {, }} \mathrm{Rh}$, and Y (used as an internal standard spike), and $8.9 \mathrm{ml} 2 \% \mathrm{HNO}_{3}$ was analyzed using an inductively coupled plasma mass spectrometer (ICP-MS; Thermo model iCAP $\mathrm{RQ)}$ for bulk Ca determination. Samples were analyzed for ${ }^{43} \mathrm{Ca}$ and ${ }^{44} \mathrm{Ca}$. Raw elemental intensities in counts $\mathrm{s}^{-1}$ were blank-corrected, further corrected for ${ }^{87} \mathrm{Sr}^{2+}$ interference and instrumental drift with internal standardization before conversion to concentrations (ppm). ${ }^{43} \mathrm{Ca}$ intensities were used to calculate final Ca concentrations and were converted to total Ca (mg) using exact dilution factors for each sample, and normalized to either weight of skeleton (Part A), as an assessment of skeletal composition, or to area of the sample (Parts A + B), as a measure of skeletal density.

\section{Statistical analyses (Parts 1-3)}

For each experimental response variable, a series of linear or generalized linear mixed effects models were used to test $\mathrm{pH}$ and predation cue as fixed effects and included colony as a random effect to account for variation across genotypes. Quadratic relationships, using $\mathrm{pH}^{2}$ as a fixed effect, were also tested for the response variables growth rate, zooid senescence and skeletal density, which displayed non-linear trends with respect to $\mathrm{pH}$. Akaike's information criterion (AIC) was used to determine the best fitting model for all analyses (see Supplement 1). For growth rate analysis, linear mixed effects models with identity link functions and Gaussian response distributions tested main effects of $\mathrm{pH}, \mathrm{pH}^{2}$ and predation cue. Zooid senescence was presented as a proportion of degenerated zooids relative to total colony zooids, and generalized linear mixed effects models with logit link functions and binomal response distributions tested main effects of $\mathrm{pH}, \mathrm{pH}^{2}$ and predator cue. For spine length analysis, linear mixed effects models with identity link functions and Gaussian response distributions with an additional nested random effect of colony section within colony tested for fixed effects of $\mathrm{pH}$ and predator cue. For Corambe zooid consumption rate analysis, generalized linear mixed effects models with log link functions and a Poisson distribution tested the main effects of $\mathrm{pH}$ and previous colony predator exposure (defended vs. undefended colonies) with nudibranch length as a covariate and colony, nudibranch and colony size included as random effects. For skeletal density analysis, linear mixed effects models with an identity link function and a Gaussian distribution 
tested the fixed effects of $\mathrm{pH}, \mathrm{pH}^{2}$ and predation cue. Statistical analyses were conducted in R v.3.4.1 (R Core Team 2017) using the 'Ime4' package (Bates et al. 2014) to construct mixed effects models.

\section{Part 4: Integrating experimental data into bryozoan population dynamics model}

A spatially explicit population dynamics model was constructed to investigate the implications of empirically determined colony growth rates for Membranipora population structure, distributions and space competition. The model approximates Membranipora colonies as aggregations of repeating hexagons representing zooids. These hexagons, with side length $p$ and acute angle $\theta$, fit together in an approximately circular form if $\pi / \theta$ is an integer (Fig. 2) (Grünbaum \& Shephard 1987). Modeled zooids are not exact replicates of zooid geometry, but are the most similar polygons that can fully tile the plane without gaps or alterations in shape.

The model accounts for the key processes of energy acquisition by mature feeding zooids, translocation of that energy to the growing edge to support formation and development of new zooids and occlusion by neighboring colonies preventing new zooid formation. Colony growth is mediated through zooidlevel algorithms for energy translocation. A system of ordinary differential equations is used to describe changes in zooid energy content, mass and developmental state over time. The rate of change of energy content of the $j^{\text {th }}$ zooid is defined as:

$$
\frac{\mathrm{d} E_{\mathrm{tot}_{j}}}{\mathrm{~d} t}=q_{\mathrm{in}_{j}}+q_{f_{j}}-q_{\mathrm{out}_{j}}-q_{g_{j}}-q_{m_{j}}
$$

where $E_{\text {tot } j}$ is the total available energy content of zooid $z_{j i} q_{\text {in }}$ is the rate of energy translocated into zooid $z_{j}$ from upstream neighboring zooids; $q_{\text {out } j}$ is the rate of energy translocated out of zooid $z_{j}$ to downstream neighbors; $q_{f j}$ is the rate of energy intake from feeding; $q_{g_{j}}$ is the rate of energy allocated for the production of zooid tissue; and $q_{m j}$ is the rate of energy allocation for basal metabolism. All rates have units of $\mathrm{J} \mathrm{d}^{-1}$. Additional equations and parameters specifying how each term is calculated are presented in Text S1 \& Table S1.

\section{Model parameters}

The model, implemented in Python v.2.7, establishes a 2D domain which simulates a kelp blade randomly seeded with Membranipora colonies that grow and compete for space. Colony growth rate is not an explicitly designated parameter in the model, but is an emergent property of energy and growth dynamics within colonies. Model parameters were adjusted to achieve the correct range of growth rates determined from experiments (see Table 2). Model colony growth rates were calculated using the slope of log-transformed colony area versus time between Days 20 and 35 of the simulation, corresponding to the method by which growth rates were experimentally determined. In the model, colony growth rates were driven by the combined parameter $\Delta q=q_{f}-q_{m}$ i.e. the difference between energy input from feed-

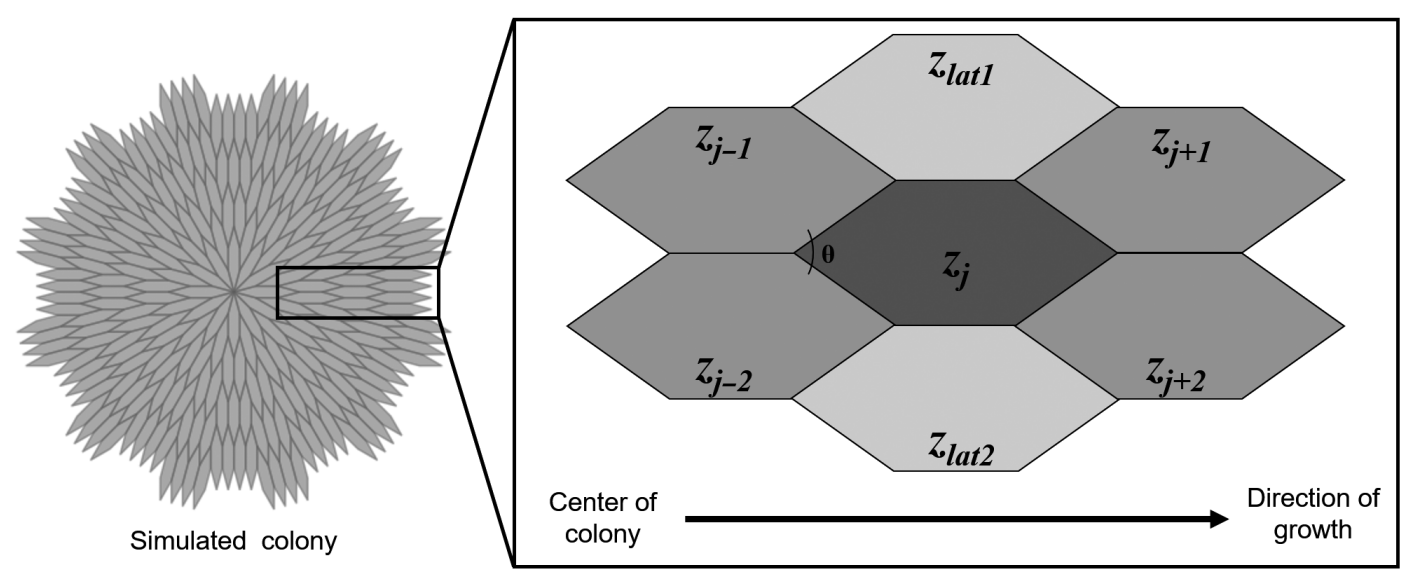

Fig. 2. Basic zooid connection pattern within a simulated Membranipora colony, showing connections between zooids within

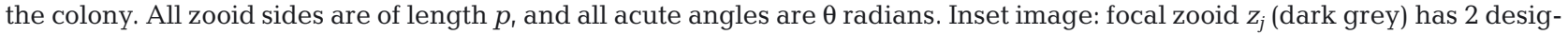
nated types of neighbors for approximating energy translocation through a colony: axial (mid grey) and lateral (light grey). 'Upstream' neighbors (sources of translocated metabolites) of $z_{j}$ are axial neighbors $z_{j-1}, z_{j-2}$, and lateral neighbors $z_{l a t 1}$ and $z_{l a t 2}$. 'Downstream' neighbors (sinks of translocated metabolites) of $z_{j}$ are axial neighbors $z_{j+1}, z_{j+2}$, and lateral neighbors $z_{l a t 1}$ and $z_{\text {lat2. }}$. Note the bidirectional connections between lateral neighbors 
ing and basal metabolic rate. Therefore, we adjusted $\Delta q$ to generate simulated growth rates for several single, unoccluded colonies (Fig. 3). We then linearly interpolated across calculated $\Delta q$ values to find values resulting in growth rates that matched experimentally determined values for each $\mathrm{pH}$ and predator condition (see Table 2).

We used model simulations to test consequences of space limitation and competition on the cost of defense and OA effects. These simulations contained 16 simultaneously settled colonies. We used 2 types of simulations, one set with all 16 colonies growing with the defended colony growth rate or undefended colony growth rate at each $\mathrm{pH}$ (10 replicate runs), and a second set of simulations containing 8 colonies with $\mathrm{pH}$-specific undefended colony growth rates and another 8 colonies with the defended colony growth rates (25 replicate runs). Simulations were $75 \mathrm{~d}$ long with $0.5 \mathrm{~d}$ time step intervals, approximating the length of Membranipora growing season. Model domain dimensions were $50 \times 100 \mathrm{~mm}$, a smaller scaled estimate of typical kelp blade area, with typical settlement densities (Seed 1976, Yoshioka 1982a). Smaller domain sizes allowed us to acquire similar space competition data without the computational expense required for larger domain sizes representative of actual kelp blade sizes. Colony areas at each time step were averaged to account for edge effects, and plotted as growth trajectories over $75 \mathrm{~d}$. Growth trajectories from both types of simulations were compared to establish the cost of defense in the context of competition with colonies of

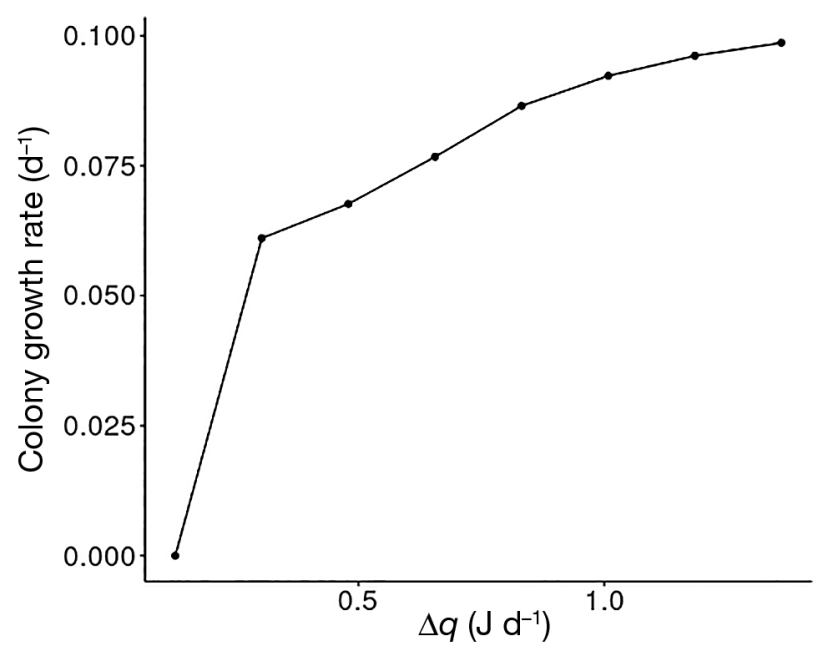

Fig. 3. Relationship between $\Delta q$ (difference between energy input from feeding and energy output to basal metabolic rate) and Membranipora colony growth rate in modeled colonies. This plot shows simulated growth rates in single, unoccluded (non-space limited) colonies across a range of $\Delta q$ values. Other parameters are fixed as described in Table S1 identical growth rates, versus competition between colonies of different growth rates.

Using average colony growth trajectories over time, we calculated 2 metrics to compare the cost of defense in simulations with colonies of identical growth rates versus simulations with undefended and defended colony competition. We defined the intra-population cost of defense as the difference in mean colony area from populations of uniform growth rate, corresponding to either all defended or undefended colonies, at the time when undefended colonies have filled the domain. We defined a full domain at the time at which the increase in mean colony area decreased below $0.5 \mathrm{~mm}^{2}$. We defined the inter-population cost of defense as the difference in mean colony area between undefended and defended colonies at the end of a $75 \mathrm{~d}$ duration, from model simulations where equal numbers of both colony types competed against each other for space. These cost metrics were used as area-based fitness proxies for each $\mathrm{pH}$.

\section{RESULTS}

\section{Part 1a: Bryozoan growth rates}

Membranipora colony sections grew in all treatments (mean $\pm \mathrm{SD}$ growth rate $=0.076 \pm 0.019 \mathrm{~d}^{-1}, \mathrm{n}=$ 92; Table 2, Fig. 4a). Predator-exposed colonies exhibited slower growth rates compared with control colonies (predator cue: $\mathrm{p}=0.0003$ ), representing the cost of defense; however, this effect depended on $\mathrm{pH}$ $(\mathrm{pH} \times$ predator cue: $\mathrm{p}=0.0003)$. The reduction of

Table 2. Average Membranipora growth rates for each treatment determined by experiments which were later replicated in a spatially explicit bryozoan population model. Corresponding $\Delta q$ values (i.e. the difference between energy input from feeding and energy output to basal metabolic rate) used to replicate specific treatment growth rates in the model are listed (see Fig. 3)

\begin{tabular}{|cccccc|}
\hline $\mathrm{pH}$ & Predator treatment & $\begin{array}{c}\text { Mean } \\
\left(\mathrm{d}^{-1}\right)\end{array}$ & $\mathrm{SD}$ & $\mathrm{n}$ & $\begin{array}{c}\Delta q\left(\mathrm{~J} \mathrm{~d}^{-1}\right) \\
\text { used for } \\
\text { model }\end{array}$ \\
\hline 7.9 & Control & 0.087 & 0.013 & 12 & 0.852 \\
7.6 & Predator-exposed & 0.071 & 0.017 & 11 & 0.554 \\
7.3 & Control & 0.096 & 0.014 & 12 & 1.193 \\
7.0 & Predator-exposed & 0.074 & 0.012 & 11 & 0.613 \\
& Credator-exposed & 0.087 & 0.015 & 12 & 0.858 \\
& Credaton-exposed & 0.065 & 0.012 & 11 & 0.608 \\
& & 0.012 & 12 & 0.277 \\
& & & & 11 & 0.402 \\
\hline
\end{tabular}



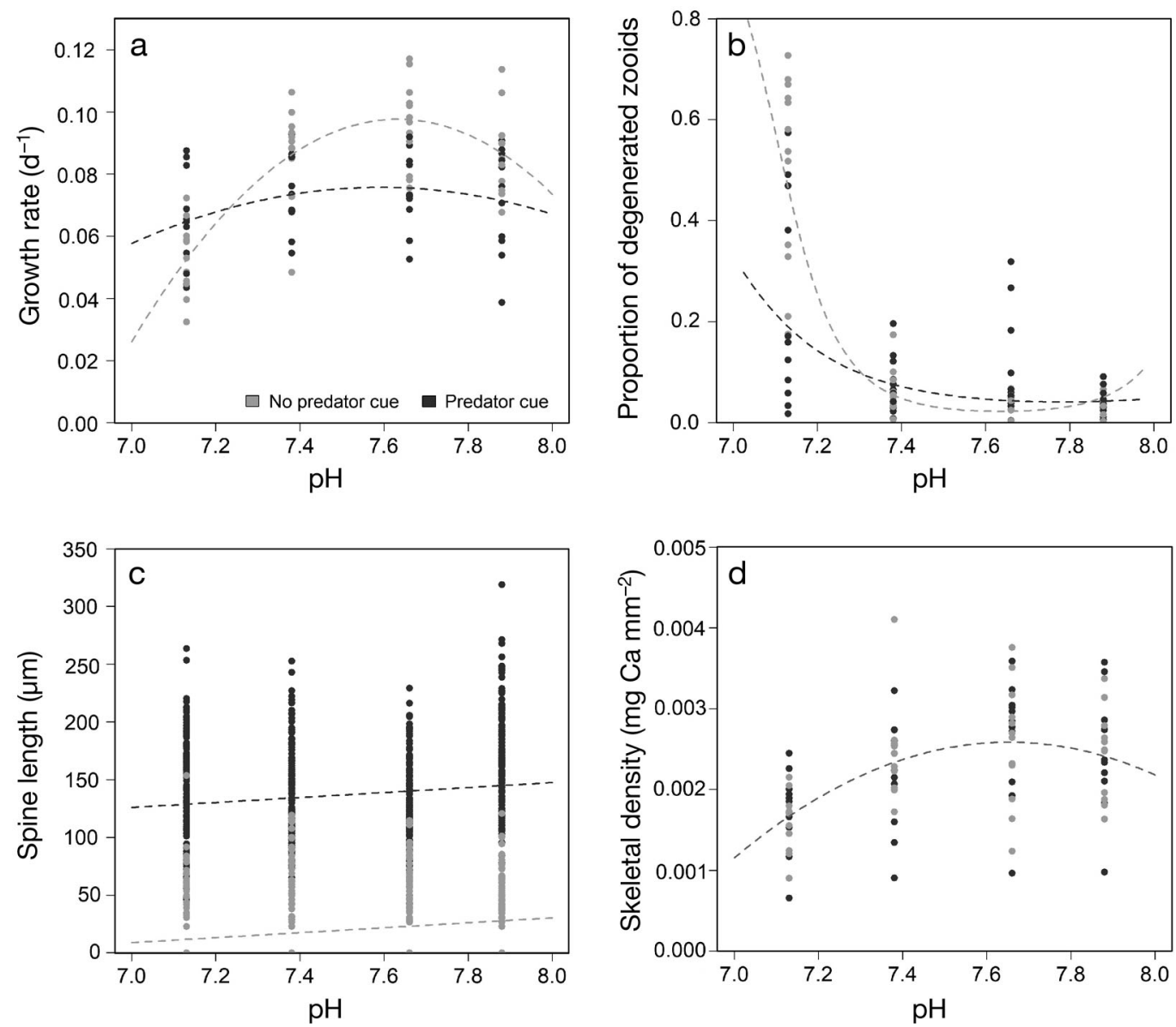

Fig. 4. Membranipora (a) growth rates, (b) colony senescence represented as a proportion (degenerated zooids/total zooids), (c) spine length (d) skeletal density for control and predator-exposed colony sections from $\mathrm{pH}$ 7.0-7.9. Trendlines for each response variable show predictions for control and predator-exposed colonies from the best fit linear or generalized linear mixed effects model. In (d), only one trendline is presented since the best fit model did not designate a significant difference between skeletal density of control and predator-exposed colonies

growth rates in predator-exposed colonies was observed in all pH treatments except 7.0 (Fig. 4a). Growth rates responded to $\mathrm{pH}$ treatments parabolically ( $\left.\mathrm{pH}^{2}: \mathrm{p}<0.0001, \mathrm{pH}: \mathrm{p}<0.0001\right)$, with the shapes of the curves dependent on predator cue $\left(\mathrm{pH}^{2} \times\right.$ predator cue: $\left.\mathrm{p}=0.0004\right)$. Both inferred growth peaks occurred at lower than ambient $\mathrm{pH}$ : 7.63 (control colonies) and 7.59 (predator-exposed colonies). Control colonies exhibited faster growth rates than predator-exposed colonies at $\mathrm{pH} 7.9,7.6$ and $7.3\left(0.016,0.022\right.$ and $0.013 \mathrm{~d}^{-1}$ faster respectively), with a peak at $\mathrm{pH}$ 7.6. At pH 7.0, model trends showed growth rates were substantially reduced in both cue and no cue treatments (Fig. 4a). Average growth rates presented in Table 2 were used to inform parameter inputs for model simulations. Complete mixed effects model analysis and best fit model output are presented in Tables S2.1 \& S2.2 in Supplement 1.

\section{Part 1b: Zooid senescence}

Zooid senescence was quantified as the number of degenerated zooids formed during the experiment as a proportion of the total zooids in the colony section $($ mean $\pm \mathrm{SD}$ proportion degenerated $=0.14 \pm 0.18, \mathrm{n}=$ 92; Fig. 4b). pH affected zooid senescence trends ( $\mathrm{pH}$ : $\mathrm{p}<0.0001)$, but was dependent on predator cue (predator cue $\times \mathrm{pH}: \mathrm{p}<0.0001)$. Both control and predator-exposed colonies exhibited parabolic senescence patterns $\left(\mathrm{pH}^{2}: \mathrm{p}<0.0001\right)$, demonstrating dramatic increases in senescence at $\mathrm{pH} 7.0$ with curves specific to predator-exposure treatment $\left(\mathrm{pH}^{2} \times\right.$ predation cue: $\mathrm{p}<0.0001)$. Control colonies expressed a $2.16 \times$ greater proportion of degenerated zooids than predator-exposed colonies only at this lowest $\mathrm{pH}$ level; senescence rates were similar across higher $\mathrm{pH}$ values (Fig. 4b). Senescence trends reflected the complement of growth rate trends observed in both 
predator and no predator cue treatments: lower average growth rates were associated with higher proportions of degenerated zooids (Fig. 4b). Complete mixed effects model analysis and best fit model output are presented in Tables S3.1 \& S3.2.

\section{Part 1c: Inducible defense formation}

Spines were formed in all treatments (mean \pm SD length $=76.33 \pm 71.94 \mu \mathrm{m}, \mathrm{n}=1350$ ), but were 117.43 $\mu \mathrm{m}$ longer on average in predator cue treatments than in control treatments (Fig. 4c). Spines were produced in some control colonies (mean length $=19.79$ $\mu \mathrm{m})$ but were significantly shorter than those produced by predator-exposed colonies (predator cue: $\mathrm{p}<0.0001$ ). A weak but significant effect of $\mathrm{pH}$ was detected for both control and predator-exposed colonies, indicating that spine length at lower $\mathrm{pH}$ was slightly decreased ( $\mathrm{pH}: \mathrm{p}=0.01)$. Complete mixed effects model analysis and best fit model output are presented in Tables S4.1 \& S4.2. Abundance of spines per treatment is presented in Fig. S2 with corresponding analyses in Tables S5.1 \& S5.2.

\section{Part 2: Nudibranch consumption rates}

Consumption rates of Membranipora zooids by Corambe were measured as the number of zooids consumed over a $24 \mathrm{~h}$ period (mean \pm SD consumption $=74.29 \pm 49.69$ zooids, $\mathrm{n}=92 ;$ Fig. 5). Spines

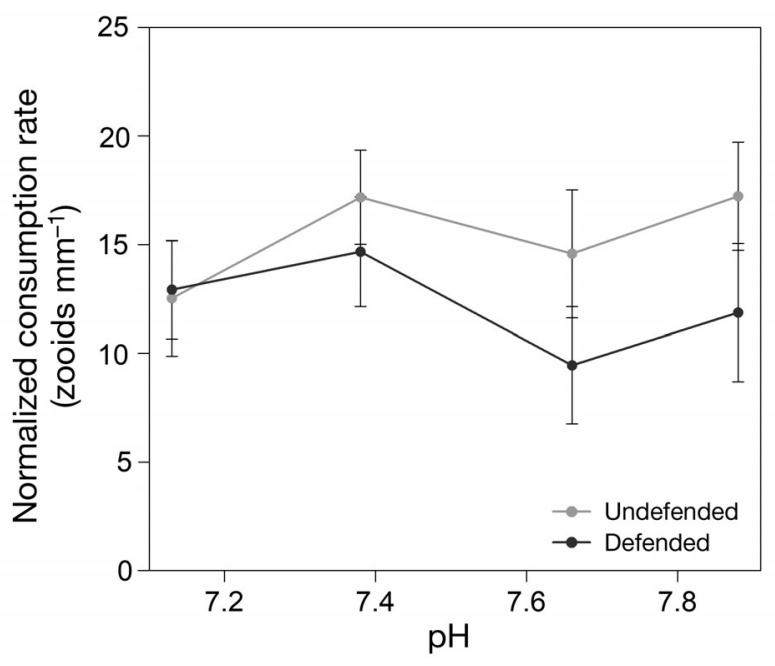

Fig. 5. Corambe consumption rates plotted as the number of Membranipora zooids consumed over $24 \mathrm{~h}$, normalized by nudibranch length in $\mathrm{mm}$. Defended colonies formed spines in the same $\mathrm{pH}$ treatments in which they were consumed. Plotted points represent means; error bars: SE. deterred feeding in nudibranchs (spine presence: $\mathrm{p}=$ 0.022) but this effect was dependent on $\mathrm{pH}$, with reduced zooid consumption rates in higher $\mathrm{pH}$ treatments but not in lower $\mathrm{pH}$ treatments (spine presence $\times \mathrm{pH}: \mathrm{p}=0.016$ ). As $\mathrm{pH}$ decreased, zooid consumption rates on control colonies decreased, while consumption rates on predator-exposed colonies increased (Fig. 5), essentially removing the benefit of defense. Nudibranch length also significantly influenced zooid consumption rate, with larger nudibranchs consuming more zooids (nudibranch length: $\mathrm{p}=0.001$ ). Complete mixed effects model analysis and best fit model output are presented in Tables S6.1 \& S6.2.

\section{Part 3: Bulk calcium content quantification of bryozoan skeletons using ICP-MS}

Total mg Ca sample ${ }^{-1}$ was calculated and normalized to skeletal area as a metric of skeletal density (Fig. 4d). Skeletal density (mean \pm SD density = $0.0023 \pm 0.0007 \mathrm{mg} \mathrm{Ca} \mathrm{mm}^{-2}, \mathrm{n}=90$ ) was significantly affected by $\mathrm{pH}(\mathrm{pH}: \mathrm{p}<0.0001)$ and displayed a parabolic trend $\left(\mathrm{pH}^{2}: \mathrm{p}<0.0001\right)$ with a weak peak at target $\mathrm{pH}$ 7.6. This peak $\mathrm{pH}$ was similar to $\mathrm{pH}$ values associated with maximum growth (control: 7.63; predator-exposed: 7.59). There was no significant difference between skeletal density of control and predator-exposed colony sections. Complete mixed effects model analysis and best fit model output presented in Tables S7.1 \& S7.2. Bulk calcium content normalized to skeletal weight is presented in Fig. S3 with corresponding analyses in Tables S8.1 \& S8.2.

\section{Part 4: Membranipora population dynamics model results}

Model output (Fig. 6) enabled visualization and quantification of predicted population-level costs of defense at different OA conditions. The cost of defense was dependent on space competition between colonies and the variations in their growth rates. In simulations where all colonies grew with identical growth rates (either defended or undefended), all colonies eventually approached the same average colony size of $250 \mathrm{~mm}^{2}$, regardless of growth rate (Fig. 7). As expected, slower-growing colonies required a longer time to reach this average size. In this case, the intra-population cost of defense demonstrated the area deficit of a slower-growing colony at the time at which the faster-growing colonies have 

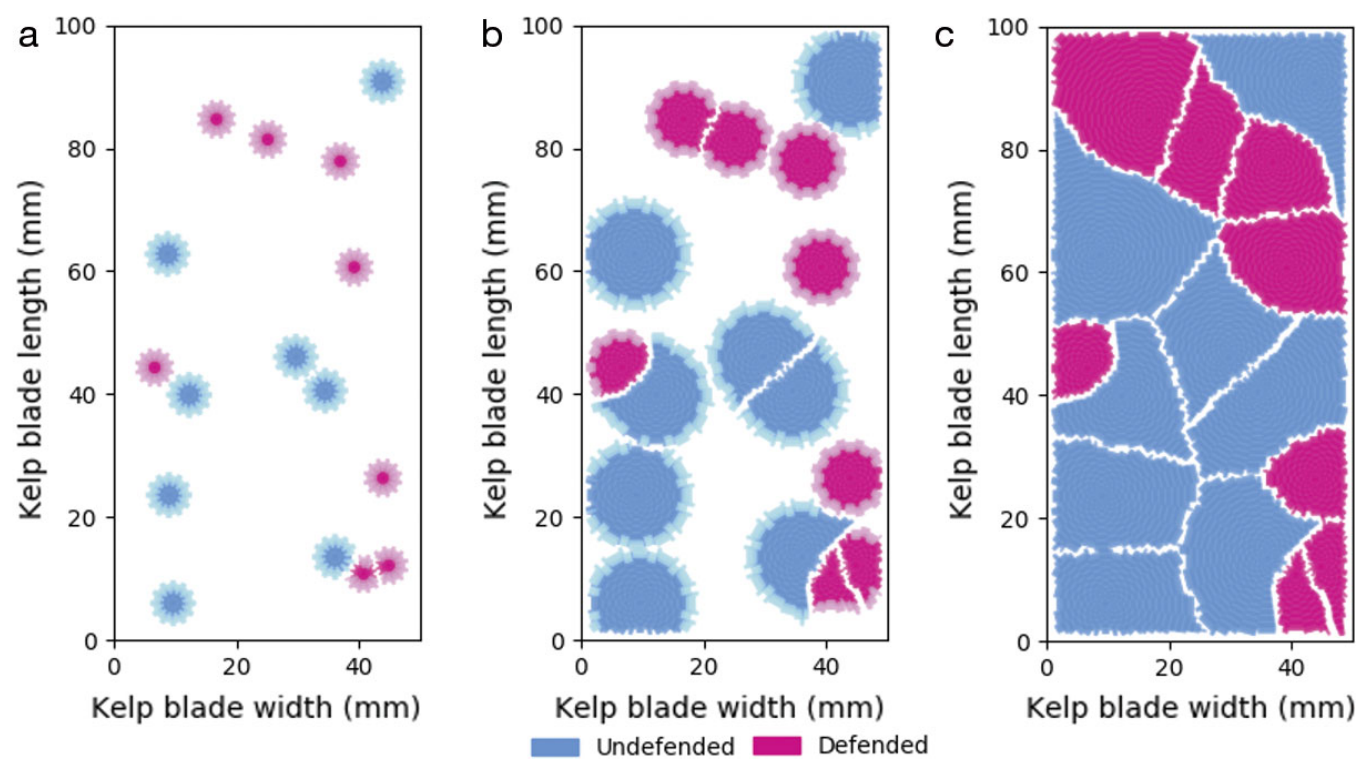

Fig. 6. Typical model output showing 16 Membranipora colonies, 8 with experimentally determined undefended (blue) and 8 with experimentally determined defended (pink) colony growth rates at $\mathrm{pH}$ 7.9. Model output is from a representative simulation run using average growth rates from pH 7.9 experimental treatments at (a) $10 \mathrm{~d}$, (b) $30 \mathrm{~d}$ and (c) $75 \mathrm{~d}$. Light blue and pink areas signify developing zooids along the colony perimeter. Model animations are presented in Videos S1-S4 in Supplement 2

filled the domain. However, this trend was dramatically altered when colonies from mixed populations containing both undefended and defended colonies competed for space. The inter-population cost of defense demonstrated the area deficit of defended colonies in comparison with undefended colonies at the end of the simulation duration. Defended, slowergrowing colonies were prevented from reaching the average size by competing undefended, fastergrowing colonies which exceeded the average size. Mixed population competition increased the cost of defense with inter-population costs of defense exceeding intra-population costs of defense between $\mathrm{pH} 7.9$ and 7.3. At pH 7.0, all colonies grew too slowly to fill the domain over a $75 \mathrm{~d}$ simulation, thus costs of slower growth using these 2 metrics could not be calculated. In addition, undefended colonies at $\mathrm{pH}$ 7.0 grew slower than defended colonies and did not exhibit a cost of defense.

Inter-population costs of defense were higher than intra-population costs of defense at $\mathrm{pH}$ 7.9-7.3. The intra-population costs of defense were calculated as $37.9,58.4$, and $17.2 \mathrm{~mm}^{2}$ for $\mathrm{pH}$ values 7.9, 7.6 and 7.3 respectively (label a in Fig. 7). In comparison, the inter-population costs of defense were much higher, at $183.2,207.5$, and $121.9 \mathrm{~mm}^{2}$ for $\mathrm{pH}$ values $7.9,7.6$ and 7.3 respectively (label b in Fig. 7). Costs of defense initially increased at mild OA conditions $(\mathrm{pH}$ 7.6) but were reduced in severe OA conditions $(\mathrm{pH}$
7.3). Compounding costs of slow growth in the context of competition resulted from a reduced growth rate and the inability to grow into space already occupied by faster-growing colonies.

In model simulations, all colonies settled simultaneously, to control for the effect of settlement time which likely influences colony competitiveness. Faster-growing colonies quickly gained an early competitive advantage over slower-growing colonies, which was maintained throughout the simulations. Overall, smaller colony growth rates yielded smaller population size structures. Population size structures are represented as density plots displaying the frequency of different sized colonies at the beginning, middle and end of model simulations (Fig. 8).

\section{DISCUSSION}

We sought to understand the impacts of OArelated stress at both the organism and population level using the bryozoan Membranipora and its specialist nudibranch predator Corambe as a case study. Using this organismal system, we developed a spatially explicit model to infer population-level consequences of experimentally determined individuallevel responses to OA, which would otherwise be difficult to assess. Key characteristics of bryozoan life history, such as the cost of defense and the impor- 


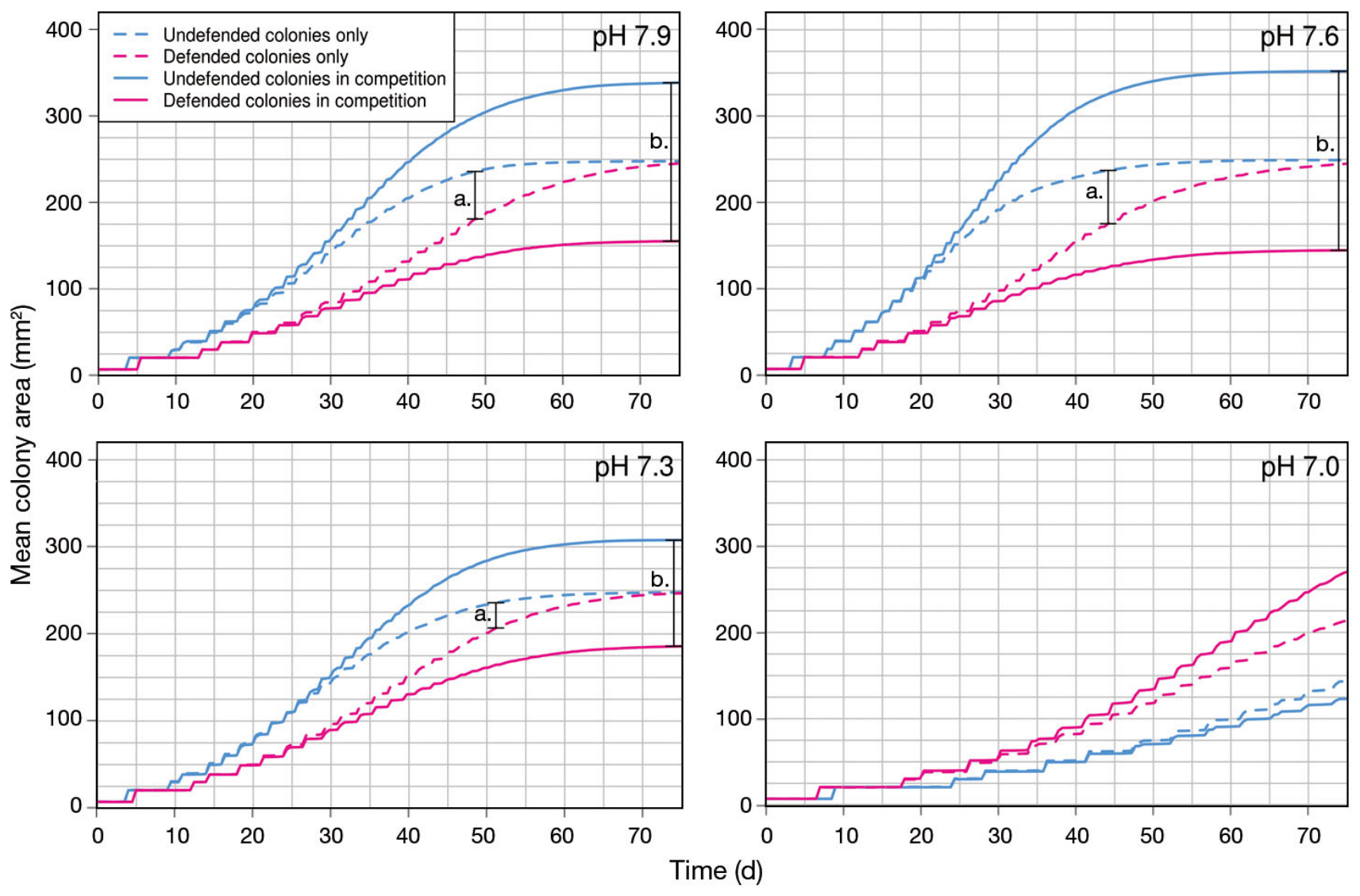

Fig. 7. Average growth trajectories of a single Membranipora colony area over a $75 \mathrm{~d}$ simulation for each pH condition. Dashed lines: mean colony areas from simulations of 16 colonies, all growing with either the undefended (blue) or defended (pink) colony growth rates. Colonies from these simulations ultimately approach a similar maximum size of $250 \mathrm{~mm}^{2}$, but differ in the time necessary to reach maximum size. Solid lines: mean colony areas for simulations where equal numbers of undefended and defended colonies (mixed population) competed for space. Plots show a comparison of the intra-population cost of defense (a) and the interpopulation costs of defense (b). Colony competition in mixed populations drives the increase in the inter-population cost of defense. At $\mathrm{pH} 7.0$, the domain was not filled after $75 \mathrm{~d}$ due to slow colony growth rates, so costs of defense are not displayed

tance of space limitation, were maintained within the range of near-future seawater $\mathrm{pH}$ projections (7.6, 7.3). At pH 7.0, likely not representative of conditions that are or will soon be experienced, we observed apparent physiological limits in Membranipora; colonies at this low pH suffered low growth rates and high zooid senescence. Here, we focus on responses and ecological interactions for $\mathrm{pH}$ 7.9-7.3, above this apparent toxicity limit. When scaled to population levels in the context of space competition, individuallevel reductions in growth rate associated with the cost of defense were amplified, resulting in multiplicative decreases in colony area, and likely reduced fitness since reproduction is generally proportional to area. The population-level cost of defense increased at moderate OA conditions but decreased at more severe OA conditions likely due to interacting effects of increased growth of undefended colonies at mod- erately low $\mathrm{pH}$ and space competition. Our results demonstrate the need to consider population-level mechanisms such as space competition when making assessments of ecological consequences of environmental stress.

\section{Membranipora growth rates and calcification under $\mathrm{OA}$}

Contrary to our hypotheses, we observed maximum growth rates near target $\mathrm{pH}$ 7.6, corresponding to a moderately high $\mathrm{pCO}_{2}$ of $985 \mu \mathrm{atm}$. This is lower than current average ambient $\mathrm{pH}$ conditions in the Salish Sea, but not outside the range normally experienced by Membranipora in the field (Murray et al. 2015). Previous studies have also documented increased growth in bryozoans at moderately low $\mathrm{pH}$ 

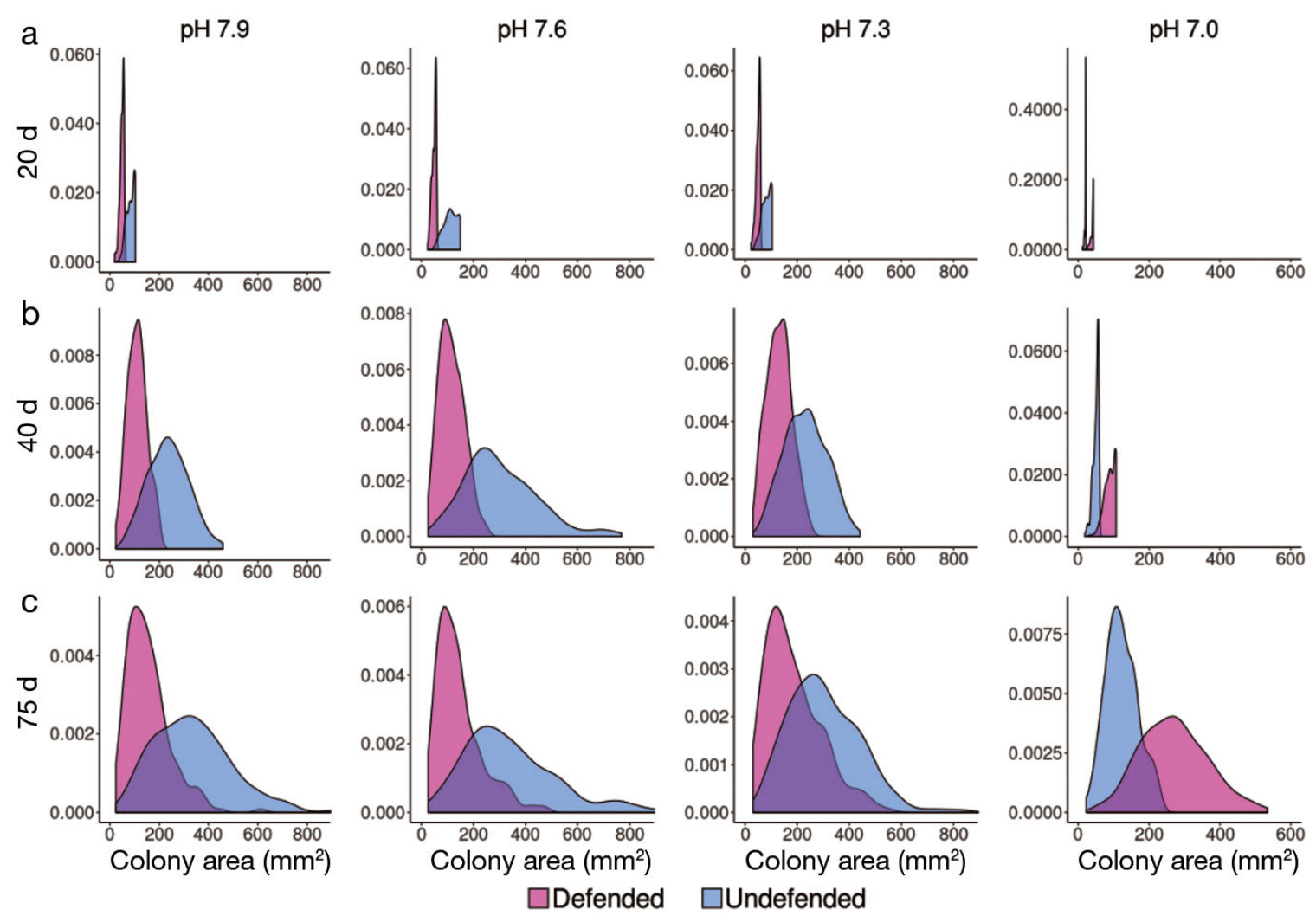

Fig. 8. Membranipora colony size distributions under space limitation at each pH condition. Comparison of model simulations of mixed populations of 8 defended (pink) and 8 undefended (blue) colonies after (a) 20 d, (b) 40 d and (c) 75 d, using growth rates from each experimental treatment (see Table 2). Within each $\mathrm{pH}$, all colonies of a given type (defended or undefended) had equal growth rates and settled at the same time. Hence, variations in size reflect only the consequences of space competition, mediated by $\mathrm{pH}$ effects and cost of defense. Each distribution represents aggregated data from all mixed population model runs. Histograms were created to establish the frequency of colony sizes at given time steps, and then converted to density plots to better visualize distributions

conditions. The calcifying bryozoans Electra pilosa (Saderne \& Wahl 2013), Celleporella cornuta (Swezey et al. 2017a) and Jellyella tuberculata (Swezey et al. 2017b) exhibited increased growth in response to moderately high $\mathrm{pCO}_{2}$, corresponding with moderately low $\mathrm{pH}$ conditions, relative to ambient (E. pilosa, $1200 \mu \mathrm{atm} ;$ C. cornuta, $1150 \mu \mathrm{atm} ;$ J. tuberculata, $1050 \mu \mathrm{atm})$. E. pilosa displayed a parabolic growth response curve exhibiting maximum growth at 1200 atm (Saderne \& Wahl 2013), similar to our results, suggesting these types of response curves may not be unusual in bryozoans.

Maximum skeletal density also occurred near target $\mathrm{pH} 7.6$, reflecting observed trends in growth rate and implying a positive relationship between growth rate and skeletal density with a possible physiological link. Observed trends in growth and calcium production could reflect the calcification mechanism used by Membranipora, which is currently poorly understood. Many calcifiers secrete $\mathrm{CaCO}_{3}$ from a calcifying fluid space of elevated $\mathrm{pH}$, making it ener- getically favorable to convert $\mathrm{HCO}_{3}{ }^{-}$to $\mathrm{CO}_{3}{ }^{2-}$ rather than extracting $\mathrm{CO}_{3}{ }^{2-}$ directly from seawater. Microelectrode studies have shown calcifying fluids to be upwards of 2 units above ambient seawater pH (AlHorani et al. 2003). Ries et al. (2009) documented increases in calcification with respect to acidification in multiple taxa of marine calcifiers, and suggested that these increases could be due to strong control over calcifying fluid $\mathrm{pH}$ and $\mathrm{H}^{+}$regulation at the calcification site used to convert $\mathrm{HCO}_{3}{ }^{-}$to $\mathrm{CO}_{3}{ }^{2-}$. In $\mathrm{C}$. cornuta, OA also increased the expression of protective organic coverings in areas of new growth, which can prevent dissolution while allowing calcification to continue (Swezey et al. 2017a). A combination of strong chemical control over a calcifying space and protective membranes might be responsible for Membranipora's robust calcification response to OA.

In the bryozoan C. cornuta, increased growth was associated with costs including reduced investment in reproduction and lighter skeletons (Swezey et al. 2017a). We did not find a cost associated with calcifi- 
cation in Membranipora. However, it is possible that our observed increases in growth and skeletal density in Membranipora are associated with costs that were not measured in this study, such as reduced per-zooid reproduction or altered metabolic costs.

\section{Spine formation in OA conditions}

Inducible spine formation was sustained across the entire range of $\mathrm{pH}$ conditions we investigated, with low $\mathrm{pH}$ correlated with slightly shorter spines. Membranipora spines are chitinous (Harvell 1984), rather than calcified, so their chemical composition may be less vulnerable to $\mathrm{pH}$ changes than zooids' $\mathrm{CaCO}_{3}$ skeletons. Predator cues in all $\mathrm{pH}$ conditions induced spines in consistent patterns, and were deposited concurrently with new skeleton formation. Induction of spines suggests that Membranipora colonies were able to detect predator cues in seawater with $\mathrm{pH}$ as low as 7.0. Shorter spines in lower $\mathrm{pH}$ may imply slight impairment of predator detection mechanisms in Membranipora due to OA. If so, this would be consistent with diminished chemosensitivity observed in other taxa (Dixson et al. 2010, Manríquez et al. 2013, Dodd et al. 2015, Weiss et al. 2018). Our observations are perhaps most analogous to Weiss et al. (2018), who documented decreases in the length of induced neck teeth in Daphnia spp. due to decreased predator-detection ability at higher $\mathrm{pCO}_{2}$. While our data do not suggest strongly impaired predator detection in Membranipora, predator cue concentrations in our treatments may have been high enough such that cues were detected despite decreased sensitivity. By using high levels of cue, we effectively tested for physiological limits to spine formation, but not cue detection thresholds. Spine formation occurred in some control colonies due to likely diffuse crosscontamination of predator cue that made it effectively a 'low predation cue' treatment. In these low-level induction conditions, abundance of corner spines decreased with decreasing $\mathrm{pH}$. This is consistent with the hypothesis that OA may affect defense formation, but only at very diffuse predator cue concentrations.

\section{Nudibranch consumption rate responses}

Zooid consumption rates by nudibranchs were slightly affected by $\mathrm{pH}$, as shown by a significant interaction of spine presence and $\mathrm{pH}$. With decreasing $\mathrm{pH}$, nudibranch consumption increased in the presence of spines. Lower pH conditions apparently reduced the benefit conferred by induced spines in higher $\mathrm{pH}$ conditions, with nudibranchs consuming nearly equal numbers of zooids from defended and undefended colonies at the lowest $\mathrm{pH}$. This trend suggests that OA stress fundamentally compromised the benefit of defenses in Membranipora, and represents potential differential effects of $\mathrm{pH}$ on predators and prey. This could have resulted from a variety of mechanisms acting on nudibranchs, bryozoans or both. OA could have effects on feeding physiology and energetic requirements in Corambe. OA stress has been shown to decrease the energetic content of some prey taxa, potentially increasing feeding rates in predators to meet their energetic requirements (Kroeker et al. 2014). Future experiments are needed to establish effects of OA on physiological processes of both Corambe and Membranipora, as we did not measure them in our study. Effectiveness of protective spines in Membranipora could also have been altered by OA. Consistent with the slight decrease in spine length at lower $\mathrm{pH}$, shorter spines may not confer the same protective advantage as the longer spines induced at higher $\mathrm{pH}$. Alternatively, OA stress may have compromised the structural integrity of spines, enabling higher consumption rates of defended zooids. OA has been shown to negatively affect defensive polymorphs in the bryozoan Schizoporella errata (Lombardi et al. 2011). While prey detection in Corambe may be sensitive to OA, like in other molluscs that have exhibited decreased sensory ability in OA conditions (Manríquez et al. 2013), our experiments did not test for impaired prey detection as Corambe was confined to a small area on top of colonies requiring only short-range detection of prey. Therefore, differences in consumption rates across $\mathrm{pH}$ are not likely due to impaired prey detection, but this mechanism may be relevant in the field and merits further investigation.

\section{Population-level insights from experimental data: inferences from a spatially explicit model}

Our experiments quantified the roughly exponential growth patterns exhibited by isolated colonies in the absence of geometric constraints on growth. The model provides insight into the implications of these different growth rates in a more realistic context where space is frequently limiting and where colony growth is constricted by dynamically interacting competitive neighbors. Compared to experimentally determined growth rates in the absence 
of space competition, simulated space limitation in our model reduced area-based colony fitness. Our results reaffirm and add quantitative detail to the importance of density-dependence in assessing Membranipora area-based colony fitness. Modeling provided new insights into effects of environmental stress, allowing us to consider population-level processes in evaluating the relative effects of $\mathrm{pH}$ and predation pressure on area-based colony fitness and competitiveness. Within the $\mathrm{pH}$ range 7.9-7.3, our model results show potential amplification of the cost of defense due to space competition pressure, demonstrating how growth patterns of competing colonies shape individual area-based fitness. Specifically, the cost of defense increased in mixed populations containing defended and undefended colonies, representing both the costs incurred by reduced growth and space occupied by faster-growing colonies. In addition to emphasizing the need to assess fitness in the context of populations, our results also highlight the selective advantages of inducibility, such that these high costs of reduced growth are minimized and only incurred when predation pressure is sufficiently high. Our model only considered intraspecific competition; however, if Membranipora is less vulnerable to OA, this may confer competitive advantage over other species with which it shares a common substrate such as other bryozoans, tunicates and epibionts experiencing space limitation.

Our model simulations represented competition between colonies that are undefended or defended throughout the entirety of their growing period, to evaluate the extremes of fitness tradeoffs associated with defenses. In the field, predation cue concentrations would need to be regularly high to maintain constant production of defenses, and positions of defended colonies would likely be dictated by predator placement in the field and not random, as used in our model. Therefore, our model simulations most accurately represent competition between constitutively spined colonies (those that are spined even in the absence of predators, which constitute $6.2 \%$ of the population; Harvell 1986) and unspined colonies. The high cost of defense in the context of space competition emphasizes the benefit of inducibility, where costs are only incurred when necessary. Predation was not included in our model, so we did not quantify the benefits of defense across OA conditions which may offset some of the predicted costs. Beyond demonstrating that both predator-prey relationships and intraspecies competition can influence OA responses in Membranipora and Corambe, our model- ing results also suggest that organismal-level effects are oftentimes insufficient to estimate populationlevel effects of environmental stress in space-limited species.

\section{Membranipora is relatively robust to OA}

Given the metrics measured in our experiments and modeled population-level effects, Membranipora in the Salish Sea appear to be less vulnerable to OA than many other calcifiers, particularly within the range of near-future predictions, and may be wellsuited to tolerate changes in ocean chemistry. This relative robustness may be in part attributable to the frequency of naturally low and fluctuating $\mathrm{pH}$ in the Salish Sea, and to conditions in their immediate microhabitats on kelp. $\mathrm{pH}$ values in the Salish Sea fluctuate seasonally between 7.9 and 7.6 (Murray et al. 2015), and have been recorded as low as 7.3 in Washington state coastal environments (Wootton \& Pfister 2012). Diffusional boundary layers on kelp can create distinctly different microenvironments for Membranipora, modulated by photosynthesis and respiration, which may provide a partial refuge from chemical changes occurring in ambient seawater (Cornwall et al. 2014). Fluctuations of oxygen concentrations and $\mathrm{pH}$ within this micro-environment may also exceed ambient conditions serving to precondition bryozoans to low $\mathrm{pH}$ environments, especially in slow-flow environments where boundary layers are thicker (Noisette \& Hurd 2018). While we considered conditions of $\mathrm{pH} 7.6$ to be suboptimal, this may not in fact be very stressful for Membranipora if it is within the $\mathrm{pH}$ range normally experienced within the boundary layer.

\section{Implications for Membranipora population dynamics}

On the east coast of North America, Membranipora is a significant invasive biofouling organism in kelp forests that contributes to kelp forest defoliation (Scheibling \& Gagnon 2009, Saunders et al. 2010). Population-level size structures in our simulations may have implications for kelp forest health, which are culturally and ecologically important ecosystems. From our study, Membranipora does not appear particularly vulnerable to OA, having maintained growth, $\mathrm{CaCO}_{3}$ production and spine formation at least to $\mathrm{pH} 7.3$, with maximum growth and calcification near $\mathrm{pH}$ 7.6. Predicted population structures of 
undefended colonies were larger under pH 7.6 conditions, suggesting Membranipora may have an invasive edge at lower $\mathrm{pH}$ conditions. Our observations and simulations of undefended colonies are most relevant for predictions of invasive potential on the east coast, since Corambe is not prevalent there (Lambert et al. 1992). Membranipora may represent an example of a relatively resilient species to ocean change as studies of increased temperature have demonstrated increased growth as well (Saunders et al. 2010), although potential interactions of OA and warming have not been investigated.

\section{CONCLUSIONS}

Our study demonstrates the need to consider both interspecific interactions and intraspecific interactions on both organism and population levels in assessments of effects of ocean acidification. Overall, Membranipora colonies were less vulnerable to moderate OA conditions than hypothesized but responses were heavily influenced by predator exposure and space competition among conspecifics. By modeling population-level processes, we were able to understand effects of individuallevel experimental responses to OA under the pressures of space limitation. More broadly, these environmentally induced geometric tradeoffs associated with space limitation can be applicable to other modular encrusting organisms affected by changing environments.

Acknowledgements. The authors gratefully acknowledge Rebecca Guenther for assistance in in the FHL OAEL, Alexander Gagnon, Tamas Ugrai and Anne Gothmann for ICP-MS assistance and data interpretation, Dianna Padilla, Drew Harvell, Terrie Klinger, Julie Keister, Scottie Henderson and Michael Temkin for help with experimental design and lab techniques, Jason Hodin for assistance with algal culturing, Alyssa Liguori, Will King, Cassandra Donatelli, Robert Levine, Mo Turner, Katie Dobkowski, Hilary Hayford and Ann Stanbrough for organism collection and laboratory assistance, Sarah Converse for statistical advice, Anna McLaskey for manuscript comments, 4 anonymous reviewers who provided helpful feedback, and the FHL director and community. Calcium measurements were conducted at the University of Washington's TraceLab established through the generous support of the M.J. Murdock Charitable Trust. This work was funded by FHL student support fellowships (Beatrice Crosby Booth Endowed Scholarship, Alan J. Kohn Endowed Fellowship, Richard and Megumi Strathmann Fellowship), NSF IGERT Program on Ocean Change, NSF Graduate Research Fellowship Program and Washington Sea Grant (NA10OAR-4170057 to D.G.).

\section{LITERATURE CITED}

Al-Horani FA, Al-Moghrabi SM, de Beer D (2003) The mechanism of calcification and its relation to photosynthesis and respiration in the scleractinian coral Galaxea fascicularis. Mar Biol 142:419-426

Bates D, Maechler M, Bolker B, Walker S (2014) lme4: linear mixed-effects models using 'Eigen' and S4. http://CRAN. R-project.org/package $=$ lme 4

* Bibby R, Cleall-Harding P, Rundle S, Widdicombe S, Spicer $\mathrm{J}$ (2007) Ocean acidification disrupts induced defenses in the intertidal gastropod Littorina littorea. Biol Lett 3: 699-701

Bourdeau PE (2010) Cue reliability, risk sensitivity and inducible morphological defense in a marine snail. Oecologia 162:987-994

*Busch S, McElhany P (2017) Using mineralogy and higherlevel taxonomy as indicators of species sensitivity to $\mathrm{pH}$ : a case-study of Puget Sound. Elem Sci Anth 5:53

Cornwall CE, Boyd PW, McGraw CM, Hepburn CD and others (2014) Diffusion boundary layers ameliorate the negative effects of ocean acidification on the temperate coralline macroalga Arthrocardia corymbosa. PLOS ONE 9:e97235

*Dickson AG (1990) Standard potential of the reaction: $\mathrm{AgCl}(\mathrm{s})+12 \mathrm{H} 2(\mathrm{~g})=\mathrm{Ag}(\mathrm{s})+\mathrm{HCl}(\mathrm{aq})$, and the standard acidity constant of the ion $\mathrm{HSO}_{4}{ }^{-}$in synthetic sea water from 273.15 to $318.15 \mathrm{~K}$. J Chem Thermodyn 22:113-127

Dickson AG, Millero FJ (1987) A comparison of the equilibrium constants for the dissociation of carbonic acid in seawater media. Deep Sea Res A, Oceanogr Res Pap 34:1733-1743

Dixson DL, Munday PL, Jones GP (2010) Ocean acidification disrupts the innate ability of fish to detect predator olfactory cues. Ecol Lett 13:68-75

* Dodd LF, Grabowski JH, Piehler MF, Westfield I, Ries JB (2015) Ocean acidification impairs crab foraging behaviour. Proc R Soc B 282:20150333

*Doney SC (2010) The growing human footprint on coastal and open-ocean biogeochemistry. Science 328:1512-1516

*Feely RA, Sabine CL, Lee K, Berelson W, Kleypas J, Fabry VJ, Millero FJ (2004) Impact of anthropogenic $\mathrm{CO}_{2}$ on the $\mathrm{CaCO}_{3}$ system in the oceans. Science 305:362-366

Feely RA, Doney SC, Cooley SR (2009) Ocean acidification: present conditions and future changes in a high- $\mathrm{CO}_{2}$ world. Oceanography (Wash DC) 22:36-47

* Ferrari MCO, Wisenden BD, Chivers DP (2010) Chemical ecology of predator-prey interactions in aquatic ecosystems: a review and prospectus. Can J Zool 88: 698-724

Findlay HS, Wood HL, Kendall MA, Spicer JI, Twitchett RJ, Widdicombe $\mathrm{S}$ (2011) Comparing the impact of high $\mathrm{CO}_{2}$ on calcium carbonate structures in different marine organisms. Mar Biol Res 7:565-575

* Fortunato H (2015) Bryozoans in climate and ocean acidification research: a reappraisal of an under-used tool. Reg Stud Mar Sci 2:32-44

Grünbaum D (1997) Hydromechanical mechanisms of colony organization and cost of defense in an encrusting bryozoan, Membranipora membranacea. Limnol Oceanogr 42:741-752

Grünbaum B, Shephard GC (1987) Tilings and patterns. WH Freeman \& Company, New York, NY

Harvell CD (1984) Predator-induced defense in a marine bryozoan. Science 224:1357-1359 
Harvell CD (1986) The ecology and evolution of inducible defenses in a marine bryozoan: cues, costs, and consequences. Am Nat 128:810-823

*Harvell CD (1990) The ecology and evolution of inducible defenses. Q Rev Biol 65:323-340

Harvell CD (1992) Inducible defenses and allocation in a marine bryozoan. Ecology 73:1567-1576

Harvell CD, Padilla DK (1990) Inducible morphology, heterochrony, and size hierarchies in a colonial invertebrate monoculture. Proc Natl Acad Sci USA 87:508-512

Hofmann GE, Barry JP, Edmunds PJ, Gates RD, Hutchins DA, Klinger T, Sewell MA (2010) The effect of ocean acidification on calcifying organisms in marine ecosystems: an organism-to-ecosystem perspective. Annu Rev Ecol Syst 41:127-147

Kroeker KJ, Kordas RL, Crim R, Hendriks IE, Ramajo L, Singh GS, Gattuso JP (2013) Impacts of ocean acidification on marine organisms: quantifying sensitivities and interaction with warming. Glob Change Biol 19: 1884-1896

Kroeker KJ, Sanford E, Jellison BM, Gaylord B (2014) Predicting the effects of ocean acidification on predatorprey interactions: a conceptual framework based on coastal molluscs. Biol Bull (Woods Hole) 226:211-222

Lambert WJ, Levin PS, Berman J (1992) Changes in the structure of a New England (USA) kelp bed: The effects of an introduced species? Mar Ecol Prog Ser 88:303-307

Lee K, Kim TW, Byrne RH, Millero FJ, Feely RA, Liu YM (2010) The universal ratio of boron to chlorinity for the North Pacific and North Atlantic oceans. Geochim Cosmochim Acta 74:1801-1811

* Leonard GH, Bertness MD, Yund PO (1999) Crab predation, waterborne cues, and inducible defenses in the blue mussel, Mytilus edulis. Ecology 80:1-14

* Lombardi C, Gambi MC, Vasapollo C, Taylor P, Cocito S (2011) Skeletal alterations and polymorphism in a Mediterranean bryozoan at natural $\mathrm{CO}_{2}$ vents. Zoomorphology 130:135-145

Lord JP, Whitlatch RB (2012) Inducible defenses in the eastern oyster Crassostrea virginica Gmelin in response to the presence of the predatory oyster drill Urosalpinx cinerea Say in Long Island Sound. Mar Biol 159: $1177-1182$

Manríquez PH, Jara ME, Mardones ML, Navarro JM and others (2013) Ocean acidification disrupts prey responses to predator cues but not net prey shell growth in Concholepas concholepas (loco). PLOS ONE 8:e68643

Mehrbach C, Culberson CH, Hawley JE, Pytkowicz RM (1973) Measurements of the apparent dissociation constants of carbonic acid in seawater at atmospheric pressure. Limnol Oceanogr 18:897-907

Miner BG, Sultan SE, Morgan SG, Padilla DK, Relyea RA (2005) Ecological consequences of phenotypic plasticity. Trends Ecol Evol 20:685-692

* Murray JW, Roberts E, Howard E, O'Donnell M, Bantam C, Carrington E, Fay A (2015) An inland sea high nitratelow chlorophyll (HNLC) region with naturally high $\mathrm{pCO}_{2}$. Limnol Oceanogr 60:957-966

Noisette F, Hurd C (2018) Abiotic and biotic interactions in the diffusive boundary layer of kelp blades create a potential refuge from ocean acidification. Funct Ecol 32: 1329-1342

' O'Donnell MJ, George MN, Carrington E (2013) Mussel byssus attachment weakened by ocean acidification. Nat Clim Chang 3:587-590
Orr JC, Fabry VJ, Aumont O, Bopp L and others (2005) Anthropogenic ocean acidification over the twenty-first century and its impact on calcifying organisms. Nature 437:681-686

Pierrot D, Lewis E, Wallace DWR (2006) MS Excel program developed for $\mathrm{CO}_{2}$ system calculations. ORNL/CDIAC105a. Carbon Dioxide Information Analysis Center, Oak Ridge National Laboratory, US Department of Energy, Oak Ridge, TN

Pratt MC, Grason EW (2007) Invasive species as a new food source: Does a nudibranch predator prefer eating an invasive bryozoan? Biol Invasions 9:645-655

R Core Team (2017) R: a language and environment for statistical computing. R Foundation for Statistical Computing, Vienna. www.r-project.org

Reibesell U, Fabry VJ, Hansson L, Gattuso JP (2010) Guide to best practices for ocean acidification research and data reporting. Publications Office of the European Union, Luxembourg

Kies JB, Cohen AL, McCorkle DC (2009) Marine calcifiers exhibit mixed responses to $\mathrm{CO}_{2}$-induced ocean acidification. Geology 37:1131-1134

* Saderne V, Wahl M (2013) Differential responses of calcifying and non-calcifying epibionts of a brown macroalga to present-day and future upwelling $\mathrm{pCO}_{2}$. PLOS ONE 8: e70455

* Saunders MI, Metaxas A (2009) Effects of temperature, size, and food on the growth of Membranipora membranacea in laboratory and field studies. Mar Biol 156: 2267-2276

Saunders MI, Metaxas A, Filgueira R (2010) Implications of warming temperatures for population outbreaks of a nonindigenous species (Membranipora membranacea, Bryozoa) in rocky subtidal ecosystems. Limnol Oceanogr 55:1627-1642

Scheibling RE, Gagnon P (2009) Temperature-mediated outbreak dynamics of the invasive bryozoan Membranipora membranacea in Nova Scotian kelp beds. Mar Ecol Prog Ser 390:1-13

* Scherer AE, Bird CE, McCutcheon MR, Hu X, Smee DL (2018) Two-tiered defense strategy may compensate for predator avoidance costs of an ecosystem engineer. Mar Biol 165:131

Seed R (1976) Observations on the ecology of Membranipora (Bryozoa) and a major predator Doridella steinbergae (Nudibranchiata) along the fronds of Laminaria saccharina at Friday Harbor, Washington. J Exp Mar Biol Ecol 24:1-17

Smith AM (2009) Bryozoans as southern sentinels of ocean acidification: a major role for a minor phylum. Mar Freshw Res 60:475-482

Smith AM, Key MM Jr, Gordon DP (2006) Skeletal mineralogy of bryozoans: taxonomic and temporal patterns. Earth Sci Rev 78:287-306

Strathmann RR (2014) Culturing larvae of marine invertebrates. In: Carroll D, Stricker S (eds) Developmental biology of the sea urchin and other marine invertebrates. Methods in molecular biology: methods and protocols. Humana Press, Totowa, NJ, p 1-26

Sullivan CA (2012) Carbonate chemistry in the San Juan Channel: characterization and suggestions for mitigation. MSc thesis. University of Washington, Seattle, WA

Swezey DS, Bean JR, Hill TM, Gaylord B, Ninokawa AT, Sanford E (2017a) Plastic responses of bryozoans to ocean acidification. J Exp Biol 220:4399-4409 
Swezey DS, Bean JR, Ninokawa AT, Hill TM, Gaylord B, Sanford E (2017b) Interactive effects of temperature, food and skeletal mineralogy mediate biological responses to ocean acidification in a widely distributed bryozoan. Proc R Soc B 284:20162349

Taylor PD, Lombardi C, Cocito S (2015) Biomineralization in bryozoans: present, past and future. Biol Rev Camb Philos Soc 90:1118-1150

Tollrian R, Harvell CD (1999) The ecology and evolution of inducible defenses. Princeton University Press, Princeton, NJ

Trussell GC, Nicklin MO (2002) Cue sensitivity, inducible defense, and trade offs in a marine snail. Ecology 83: 1635-1647

Weiss LC, Pötter L, Steiger A, Kruppert S, Frost U, Tollrian R

Editorial responsibility: James McClintock,

Birmingham, Alabama, USA
(2018) Rising $\mathrm{pCO}_{2}$ in freshwater ecosystems has the potential to negatively affect predator-induced defenses in Daphnia. Curr Biol 28:327-332

*Wood HL, Spicer JI, Widdicombe S $(2008)$ Ocean acidification may increase calcification rates, but at a cost. Proc $\mathrm{R}$ Soc B 275:1767-1773

Wootton JT, Pfister CA (2012) Carbon system measurements and potential climatic drivers at a site of rapidly declining ocean $\mathrm{pH}$. PLOS ONE 7:e53396

Yoshioka PM (1982a) Role of planktonic and benthic factors in the population dynamics of the bryozoan Membranipora membranacea. Ecology 63:457-468

Yoshioka PM (1982b) Predator-induced polymorphism in the bryozoan Membranipora membranacea (L.). J Exp Mar Biol Ecol 61:233-242

Submitted: June 22, 2018; Accepted: October 19, 2018

Proofs received from author(s): November 12, 2018 